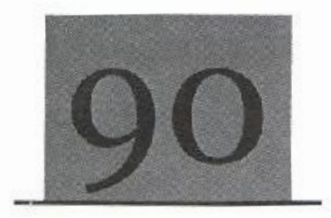

\title{
Public relations and extension services in Nigerian fisheries industry
}

\author{
Bolarinwa, J. B.
}

\begin{abstract}
:
The paper discussed the importance of fish as a food commodity and the rich, icthyofauna resources of Nigerian territorial waters which has not been optimally utilized to be sustainable. Among the challenges facing the fisheries subsector of Nigerian economy apart from averfishing, poor post-harvest technology and high incidence of sea piracy is poor level of communications, public relations and restricted access to extension services especially to the rural artisanal fisherfolksifish farmers in Nigeria. This has been identified as contributory to the increasing shortfall between demand and supply of fish in Nigeria. There is a need for a gond public image of big fisheries concerns. Production and markeing personnel need to respect the wishes of the consumers and have good interpersonal relaiionships. Communication should be a 2-way affair between the extension ufficers and the fisher folks in the rural communities for goals to be achieved. The various media that conld aid better dissemination in the Fisheries subsector were highlighted. The auihor recommended better funding, training of extensionists and target audience, improved public sensitization of rural practitioners to increase fish output. There is a need for a more productive and result-sriented reform in Nigerian extension system. A tuified extension method is also recommended for effective extension education from the stage of production, handling processing, transport and retailing. A more conducive enabling environment should be created by the government.
\end{abstract}

Keywords: Public relations, communication, funding, icthyofauna, extensionists, fisherfolks. .

\section{Introduction:}

$\mathrm{T}$ The importance of fish as a food commodity in societies varies from region to region. In the early days of man, it has been proved by ancient remnants (especially shellfish) to be important as a food item as from even the prehistoric era. There is even ample evidence from cave dwelling populations in the Dordogne (France) that in order to store surpluses of fish, preservation techniques were developed for sea fish as early as about $40,000 \mathrm{BC}$. Later on, the historical importance of fish and meat as a main diet component decreased, most probably because increased population pressure forced cereals on the scene as bulk food. Most fish species become food for the poor although less common highly-prized ones always have always remained a "luxury" commodity even up till now (Bolarinwa, 2012; Areola,2009).

According to FAO report in 1992, fish constitutes majority the source of animal protein in Africa. $21 \%$ of global fish is output of consumed by Africans despite the fact that the continent is the lowest producer of fish in the World (FAO, 2004). Fisheries in Nigeria as an cconomic activity are still on a low-scale despite the wide and rich icthyofauna of the country. The low output could be attributed to the high level of overfishing and total disregard to management regulations of out territorial water. The decimation of the fish stock is what is responsible for the increasing interest in aquaculture or fish farming. This culture form of fish production is regarded as being less risky, capital - intensive and more environmentally- friendly. Apart from these, there is market - oriented production of aquaculture products as against production -oriented marketing of captured fishery products (Fashakin, 2008; Nwabeze, 2007).

Presently, the demand for fish for outstrips the supply of food. Most of the production are also poorly handled and marketed after harvest resulting in fish of doubtful, quality inadequate processing and marketing infrastructure are main handicaps and these have been held responsible for the erratic change in price. Fish is no more a cheap source of protein especially in Lagos where an average man can hardly afford to buy fish. There is therefore a need to get out of subsistent level of fish production. The calls for increased awareness campaign of the benefits of fisheries (especially fish farming). This is where public relations and extension services come into play. The sale of operation if increased would result in higher output of fish which would entail more aggressive marketing strategics and public relations. The immense importance as pastime and as an income generating investment needs be highlighted to the populace. The FOS/UNDP Baseline survey conducted in 1997 
revealed the low level of fisheries in the country when compared with other forms of agriculture. It also has the most restricted access to extension services, hence the need for public relations especially the area of culture fisheries.

Bccause of the present low level of sensitization on the immense potential of fisheries in Nigeria, there is a serious need to incorporate public relations into the sector especially the relatively virginal aquacultural form. According to FOS/ UNDP Baseline survey (1997), culture fisheries has the most restricted access to extension services and credit even agricultural lending officers are skeptical about granting loans for fisheries project because of inadequate technical knowhow, there is therefore a need to educate the pcople on the immense beneficial potential of fisheries, so that it would not be regarded as a 'no go area again' by the by the agricultural lending officer. There is marginal contribution of development officers and extension officers to development of aquaculture in few rural areas (Ezenwa et al, 2001) all activities designed to build good relationship towards our business organization. Apart from selling goal, a sympathetic and favorable public recognition of the firm and products is secured, thus creating a favorable atmosphere for doing business by building a friendly feeling for the firm in public (including government, stakeholders, middlemen, suppliers, employees, customers and competitors, news media and community at large. Promotional selling efforts are made much easier once the goodwillipublic relations is built.

FAO (2001) advocated a holistic approach to fisheries planning for technological transfer in rural arcas. There should be strong links between rescarchers-farmersion-farm and on-station researchersiresearcher and icchnology transfer workersi technology transfer workers-farmers.

Baker and Baker (1995) stressed the need for a well-articulated communication network requiring participatory action and intervention of all stakeholders to avoid food crisis. Extensionists should concentrate on dissemination of timely in formation to farmers and fisher folks.

Public relations consist of all activities designed to build good relationships towards our business organization. Apart from selling goals, sympathetic favourable public recognition of the firm and the products is secured, thus creating a favourable atmosphere for doing business by building a friendly feeling for the firm in the public (including government, stakeholders, middlemen, suppliers, employees, customers and competitors, news media and community at large). In this paper, attempt would be made at discussing public image mix, status of extension services in fisherics, role of production, personnel and the various media of public relations in fisheries

Public Image Mix and the Role of Production \& Marketing Personnel:

Public image is concerned with all aspects of the good image of the firm including its physical appearance, its relationship with employecs, trade unions customers and the whole public. There is need to be courteous respectful and friendly with customers (who are always considered to be night even when they somctimes act stupid, argumentative and unreasonable). It is the responsibility of every member of staff of a fisheries concern (most especially those in the marketing department) to follow all the principle of human relations viz self-confidence, understanding the viewpoints of others, friendliness, admission of faults. The personnel should avoid making unrcalistic promises. They should be patient, approachable self-less, sociable. There is a need for constructive criticism in good faith. These virtues are not only necessary to improve interpersonal relations will the rural populace most of whom are involved in fisheries. Extension officers, in particular need to have good human relation if they are going to achieve any success in disseminating information to the rural fisher folks. The same is applicable to salc officers and the entire staff members, all of whom should think positive towards achievement of the campaign's goals.

\section{Various Media of Public Relations in Fishery Subsector:}

The media that could build good relationship towards a fishery organization are:

1. Exhibitions in hotels or schools to display types of fishery products.

2. Trade fairs

3. Gin'free sample/charity (in money or kind).

4. Cinemas (special films to arouse consumers' interest in order to build an image for the farm.

5. Television or radio (new items).

6. Features Articles (publications of farm products or services).

7. Seminars (Workshops/Conferences (where papers are presented involving staff of the farm c.g., Fisheries Society of Nigeria).

8. Provision of After Sales Services.

9. Specialized programs

10. Discharging special responsibilitics

\section{Social Responsibilities in Fisheries:}

Even though especially fish farming is environmentally - friendly, a fisheries outfit (especially large scale type) needs to be socially responsible to the environment it is suited the rural populace should benefit from the presence of such fishery organization. A socially oriented fishery development project should aim at increasing the sell-being of the pcople and the socioeconomic benefits (e.g., employment opportunities, self-sufficiency etc).

Fisheries organizations could support special events, sponsor programs, give scholarship, organize musical concerts, football matches or other sport festivals or even part-time training for the people in the community. In short, they should contribute to the social and cultural life of the community as its being done by oil-exploring farms (Chevron, Shell, etc). 


\section{Extension Services in Fisheries:}

Management of Agriculture extension in Nigeria over time laid less emphasis on Aquaculture and fisheries extension. It was apparently deemphasized in favor of crop and livestock agriculturc. There is therefore a need for a favorable reform in Nigerian agriculture extension system where fisheries and aquaculture extension would be put in proper perspective for effective service delivery. This would be a good entry point to achieving the millennium development goods of combating hunger, extreme poverty and attainment of food security in Nigeria (Mbagwu, 2008, Kumolu Johnson and Ndimele, 2012).

Agricultural extension in Nigeria is an old development strategy for the agriculture sector. It has long been used to manage agricultural information in Nigeria with specific reference to the transfer of technological innovations to farmers in crop, livestock, forestry and fisheries and aquaculture. Fisheries and $\Lambda$ quaculture extension have not had a fair share of this development policy for Nigeria Agriculture over time probably duc to inadequacy in prioritization and the relative newness of aquaculture in Nigeria compared with crop and livestock farming (FDF, 2003, 2007).

There is need for a more productive, result-oriented reform in Nigeria's extension system which will cover all relevant aspect of agriculture, fisheries and aquaculture. Unified Agriculture Extension of ADPs has particularly succeeded in unification of message transfer to farmers but there's still a need for capacity building of the in fisheries and aquaculture.

\section{Communications and Public Relations:}

Communications according to Baker and Baker (1995) is a process for interrelated elements working to achieve a desired outcome or goal. It is dynamic or unending and characterized by Source-Message-Channel Receiver. Rural media include use of town crier, radio, press conference, village arena or market places, person-to-person contact, Focus Group Discussion (FGD), quizzes, competitions, social clubs, oral poetry, narrative, festivals, drama and folklores. Drama arouses deep psychological and cultural emotions while personal touch in behavioral changes involves having a mentor.

In urban areas, meetings, magazines, booklets, newspapers, seminars, workshops, radio and press conferences, meeting with both policy makers and politicians, extension guides, direct adverts and documentaries could be effective. Communication must be two-way for it to be effective. It is also important to install a feedback mechanism that ensure there is a feedback from the target audience (Yahrere and Ajana, 2001)

\section{Effective Communications in Fisheries:}

Marketing communication aims at attitudinal change. It has to do with dissemination of information about a product (fishery products). This could be persuasive and interpersonal for effective communication, management of people is very important. Nobody likes to be treated in a subhuman way. We all want and need to be somebody if you treat a person as he is he will contrite as he is but if you treat his as he is capable of learning, he will become what he is capable of becoming (according to Goethe), hence the need for good interpersonal relationship in a manager. The carrot and stick approach of management is not the best since humans are national beings, not mechanical, hence the need for flexibility in management of people.

In communication effectiveness with employers of a project (fisheries), keep in mind that communication is more than passing along information explaining an arraignment. It includes, friendly daily chat and greeting, ethical and straight forward statements, disagreement to agree without taking it personal (Cole, 1997, Okomoda and Ayanda, 1997). Rural psychology comes in because most of the fishermen employees are semi-illiterate and rural communicating should be in adult-to-adult fashion minimizing seniority, position and status. Manager should try to be available when needed should have time for his subordinate, seeking to understand as well as to be invested and being consistent in word and action (Yahrere and Ajana).

\section{Effective Participation in Agricultural Shows and Exhibitions}

There is a need for fisheries concerns to be involved in agricultural shows and exhibitions especially when new unfamiliar fishery products are to be marketed. Publicity is to stimulate demand apart from providing good opportunity for manufacturers/ investors, marketers and sellers to display and sell their products. Exhibitions and trade fairs have the advantage of being able to reach more prospective customers in less time than it would take sales representative to do personally apart from building goodwill among prospective customers.

\section{Conclusion and Recommendations:}

By and large there is a very serious need for effective public relations in fisheries especially in the relatively virginal aspect of culture fisheries. There is a need for more funding, more planning and more in the part of government, relevant institution and other stakcholders and donor agencies. Funding of extension management and administrative should monitor the 3-tier government. Stakeholders to be properly linked to institutions for training in fisheries. Other recommendations are

i. Promotion of fishery and aquaculture by private sector, high net worth individuals and other agencies

ii. Establishment of Agriculture Extension Trust Fund by 3-tier government (backed by from National and State Assemblies

iii. Training centers should concentrate more on courses eapable of enhancing practical competence. Training to improve technical know-how, skills and positive attitudinal change, clienteles' problem diagnostic ability, techniques of communication, management and administration of extension are needed. Induction courses and on-the-job training, special supplementary courses on extension methodology for analysis of socioeconomic conditions. 


\section{REFERENCES}

Barker, J. and Barker, O. (1995). Communicutions, London: Sage Publishcrs, 24-30.

Cole, A. A. (1997). Basic Principles of Marketing. Lagos: Adeolu Publishers, 146170.

DFID/FAO (2004): Sustainable Fisheries Livelihood Programme (SFLP): A participatory rural approach of Tatabu fishing community, Niger State, Nigeria NIFFR/GFP/INT/735, 17-19.

Ezenwa, B. I., Ayinla, O. A., Ajana, A. M. (2001): Aquaculture research-technology transfer for Rural Development. Proceedings, FISON Annual Conference. 23-26.

FOS/UNDP (1997): Baseline Survey of Agriculture, Rural Development, Health and Mass Literacy in 9 States of Nigeria. Conducted by Gothards-IHLS Consortium.

HAO (2004). The State of the World Fisheries and Aques ullure. FAO, Rome.

Fashakin, O. A. (2008). Fish as food: Yesterday, today and forever, Inaugural Lecture Series 48, FUT, Akure.

Kumolu-Johnson, C. A and Ndimele, P. E. (2010) Length-weight relationships and condition factors of 21 species of Ologe Lagoon, Lagos Statc, Asian Journal of Agricuitural Sciences 2(4): 174-179.

Mhagwu, I. G. (2008). An assessment of the prublems of fisheries data collection. Proceedings, FISON Annual Conference, 185.

Odiko, A. E. (2011). Assessment of fishing practices and their impact on the fishery or River Ovic, Edo. PhD Thesis, ГUTA.

Okomoda, J. K. and Ayanda, J. O. (1997). Aquaculture extension within the Unified Agricultural Extension System Policy: Case study of the Middle Belt ecological zone of Nigeria. NIFFR Anmul Report, Ncw Bussa, 143-145.

Nwabeze, G. O., Eric, A. P., Ifejika, P. 1., Ayanda, J. O. and Tafida, A. A. (2007). Strengthening fisheries extension under the Unitied Agricultural Fxtension System (UAES) policy towards Sustainable fisheries development. Proceedings, FISON Annual Conference, 56-58.

Sonaiya, R. O. (1998). Management and sustainability in fisherics research extension and development. Proceedings, FISON Annual Conference, 10. 